\title{
RESISTENSI BAKTERI ORAL BIOFILM TERHADAP ANTIBIOTIKA GOLONGAN BETA-LAKTAM
}

\author{
Yani Corvianindya $\mathrm{R}^{*}$, Sunarso Brotosoetarno** \\ *Bagian Biologi Oral Fakuhas Kedokteran Gigi Universitas Jember \\ **Departemen Bioiogi Oral Fakultas Kedokteran Gigi Universitas Indonesia
}

Yani Corvianindya R, Sunarso Brotosoetarno. Resistensi bakteri oral biofilm terhadap antibiotika golongan beta-laktam. Indonesian Journal of Dentistry 2004; 11(2): 83-87.

\begin{abstract}
The multi species oral bacterial biofilm contributs to plaque formation, tooth caries, infection of oral mucosa and also periodontal disease. Caries prevention is possible by controlling the bacterial population, eg by application of antibiotics. The use of antibiotics in this way is not curative but still effective on topical application. Betalactam antibiotics are drugs of choise because most oral infections are caused by mixture of anaerobic bacteria. The peptidoglican reaction in bacterial cell walls by betalactam resuls in bacterial lysis. Recently, bacterial resistance to betalactam antibiotics has been found to occur ftequently by several cellular mechanisms, such as bacterial production of $\beta$ - lactamase, mutation of penici.llin-binding protein (PBP) with. low affinity to antibiotics, or decrease of cell wall permeability to betalactam. Bacteria can acquire resistance genes by mutation or exchange of genes.
\end{abstract}

Keyword: bacterial population controle, antibiotics application, drugs of choice

\section{Pendahuluan}

Perkembangan metode pencegahan terhadap karies gigi tergantung pada perkembangan konsep tentang etiologi karies itu sendiri. Salah satu cara untuk mencegah terjadinya karies adalah dengan menghambat aktivitas bakteri rongga mulut Untuk mengendalikan aktivitas bakteri tersebut, dapat dilakukan dengan menggunakan bahan antimikroba sebagai pencegah pembentukan plak gigi.'

Sejumlah bahan antimikroba yang digunakan untuk menghambat bakteri biofilm telah dikembangkan pada tingkat organisme, seluler bahkan molekuler. Untuk mengetahuinya diperlukan pendekatan secara kom-perehensif paradigma biologi tentang komunitas biofilm dan hal yang ber- hubungan dengan mikroba, misalnya infeksi campur (mix infection) dan karies (tooth decay). ${ }^{2}$

Bakteri biofilm adalah pelbagai jenis mikroorganisme yang saling berhubungan satu sarna lain dan merupakan suatu substrat yang solid berupa matriks eksopolimer, merupakan flora normal rongga mulut, tetapi dapat juga menimbulkan penyakit. Di dalam mulut, terdapat multi 
spesies bakteri biofilm yang tidak hanya berhubungan dengan pembentukan plak gigi dan karies, tetapi juga dapat menyebabkan infeksi pada jaringan lunak dan jaringan periodontal. $^{3}$

Salah satu konsep pencegahan karies dapat dilakukan dengan tindakan mengontrol populasi bakteri, yaitu dengan obat antibiotika. Penisilin adalah jenis antibiotika betalaktam yang pertama kali digunakan, karena dapat menekan pertumbuhan dan perkembangbiakan mikroorganisme rongga mulut. Kanamisin termasuk antibiotika yang stabil. tidak mudah diabsorbsi dan banyak digunakan sebagai bahan antiplak, sedangkan vankomisin umumnya diberikan dalam bentuk obat kumur atau topikal. Namun pada umumnya antibiotika seperti ampicillin yang mempunyai struktur cincin $\beta$-laktam kurang efektif untuk berpenetrasi ke dalam matriks biofilm. Beberapa strain bakteri oral biofilm dapat memproduksi enzim 13-laktamase yang dapat menghancurkan cincin $\beta$-laktam yang terdapat pacta struktur antibiotika golongan betalaktam, sehingga menurunkan kerja ampicillin. Selain itu telah banyak bakteri yang diketahui mengembangkan sistem pertahanannya melawan serangan antibiotika, sehingga menjadi resisten. ${ }^{1,2,4}$

Pada makalah ini akan dibahas bagaimana resistensi bakteri oral biofilm terhadap antibiotika terutama golongan beta-laktam dan mekanisme molekulerya.

\section{Plak gigi sebagai oral biofilm}

Plak gigi adalah suatu contoh bakteri biofilm dengan beragam jenis bakteri, yang ditemukan pada permukaan gigi.
Bakteri plak yang mulanya berasal dari saliva ini tertanam dalam sebuah matriks polimer. Lapisan film yang terdiri dari protein dan glikoprotein dengan cepat terabsorbsi lagi ke permukaan gigi, setelah gigi dibersihkan. Pembentukan plak melibatkan interaksi antara koloni awal bakteri dan pelikel yang terbentuk pada permukaan enamel, hingga terjadinya koagregasi bakteri. ${ }^{5}$ Flak gigi juga merupakan biofilm pertama yang dipelajari komposisi mikrobanya, atau sensitivitasnya terhadap bahan antimikroba. ${ }^{6}$

Karakteristik terpenting dari bakteri biofilm adala dapat terlindung dari sistem pertahanan tubuli. Infeksi yang disebabkan oleh bakteri biofilm pada umumnya akan menetap sampai seluruh koloni permukaan diangkat. Bakteri biofilm dapat tumbuh sebagai planktonik lfreeliving), namun sebagian besar lebih senang tumbuh dalam biofilm. Bakteri biofilm akan tumbuh optimal, bila bakteri dibiak pada media dan dieram dalam suasana anaerob. ${ }^{7,8,9}$

\section{Inaktivasi bakteri biofilm dengan antibiotika betalaktam}

Pencegahan pembentukan biofilm adalah tahap penting dalam keberhasilan profilaksis suatu infeksi. Bila pembentukan oral biofilm dapat dihambat, maka dapat mencegah terjadinya kerusakan jaringan gigi, atau karies maupun penyakit periodontaL Berbagai cara dilakukan untuk dapat menghambat atau merusak struktur biofilm. Untuk mengendalikan aktivitas bakteri, dapat dilakukan dengan menggunakan bahan antimikroba. ${ }^{1,12,13}$

Penggunaan obat antibiotika dalam hal ini bukan untuk. tujuan pengobatan, namun untuk mengontrol populasi bakteri. Oleh karena itu antibiotika diberikan dalam dosis yang tepat dan penetrasi yang tepat dimana lokasi bakteri berada. Bila dosisnya tepat, maka resistensi tidak berkembang dengan cepat dan efek samping minimal. Antibiotika golongan betalaktam banyak digunakan untuk first line therapy infeksi bakteri tertentu. ${ }^{14}$

Antibiotika golongan betalaktam banyak dipilih karena pada umumnya infeksi di rongga mulut bersifat infeksi campur baik bakteri gram positif dan negatif maupun bakteri aerob dan bakteri anaerob. Mekanisme resistensi tergantung pada perubahan dalam target antibiotika yaitu PEP (penicillin-binding protein) yang bertanggung jawab pada sintesa dinding sel dan dapat mengikat penisilin dan antibiotika lain. Reaksi peptidoglikan dengan betalaktam mengakibatkan hambatan PEP yang irreversibel dan lisisnya sel bakteri. ${ }^{15}$

Termasuk dalam antibiotika golongan beta-laktam disini adalah $^{14,15}$; 1) Penisilin, yang mempunyai sistem cincin $\beta$ laktam yang reaktif dan siklik amida. Reaksi alamiah cincin $\beta$ laktam membuat penisilin dan senyawa yang berhubungan menjadi rentan terhadap berbagai proses degradasi. Aktivitas optimal penisilin terjadi saat masa pertumbuhan terutama bakteri gram positif, karena penisilin mempengaruhi sintesis dinding gel bakteri. 2) Sefalosforin, dimana mekanisme kimiawinya membentuk. ikatan kovalen dengan PBP dan menyebabkan gel bakteri lisis.

Betalaktam diketahui sensitif terhadap asam dan terdegradasi pada pH rendah. Resistensi terhadap antibiotik betalaktam dapat terjadi melalui beberapa 
mekanisme seluler, di antaranya dihasilkannya enzim $\beta$ - lactamase oleh bakteri, mutasi PBP dengan membentuk afinitas yang rendah terhadap antilbiotika, atau menurunnya permeabilias dinding sel terhadap beta laktam. ${ }^{15}$

Pernsilin adalah jenis antibiotika yang pertama digunakan, karena dapat menekan atau menurunkan kemampuan bakteri rongga mulut Tetapi penggunaanya temyata terbukti tidak efektif. Antibiotika jenis lain adalah kanamisin dan vankomisin. Kanamisin termasuk antibiotika yang stabil, tidak mudah diabsorbsi dan banyak digunakan sebagai bahan antiplak, sedangkan vankomisin umunmya diberikan dalam bentuk obat kumur atau topikal Penggunaan antibiotika dalam waktu yang lama juga akan mengganggu keseimbangan flora normal rongga mulut. Selain itu menimbulkan beberapa strain mikroorganisme yang kemudian menjadi resisten. ${ }^{1}$

\section{Mekanisme molekuler resistensi terhadap antibotik}

Antibiotika dikenal dalam dua tipe. Pertama, antibiotika bakteriostatik dengan aktivitas menghambat perkembangan bakteri dan memungkinkan sistem kekebalan inangnya mengambil alih sel bakteri yang dihambat, contohnya tetrasiklin. Kedua, antibiotika bakterisidal yang membunuh bakteri, contohnya penisilin yang menghambat pembentukan dinding sel dan bersifat toksik pada sel bakteri.

Resistensi dapat terjadi karena adanya gen resisten. Gen resisten bakteri berfungsi melindungi terhadap inhibitory effect dari antilbiotika. Gen resisten dapat melakukan coding protein transpor membran untuk mencegah antibiotika memasuki sel
Exterior

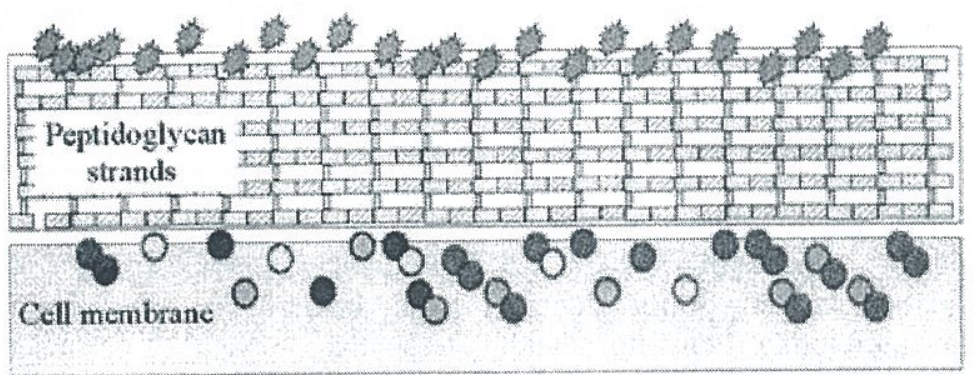

Cytoplasm

Beta-lactamase enzymes

Pericillin-binding protcins (PBP)

Exterior

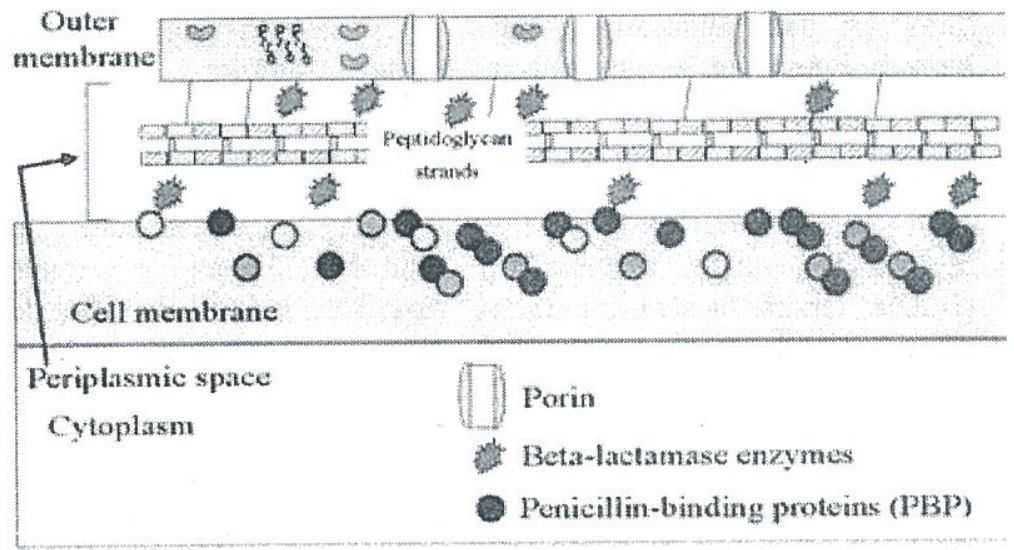

Gambar 1. Perbandingan dinding sel bakteri gram positif(A) dan gram negatif(B)

(Sumber : www.vet.purdue.edu/ gram-positive-bact-cell-wall800.jpg)

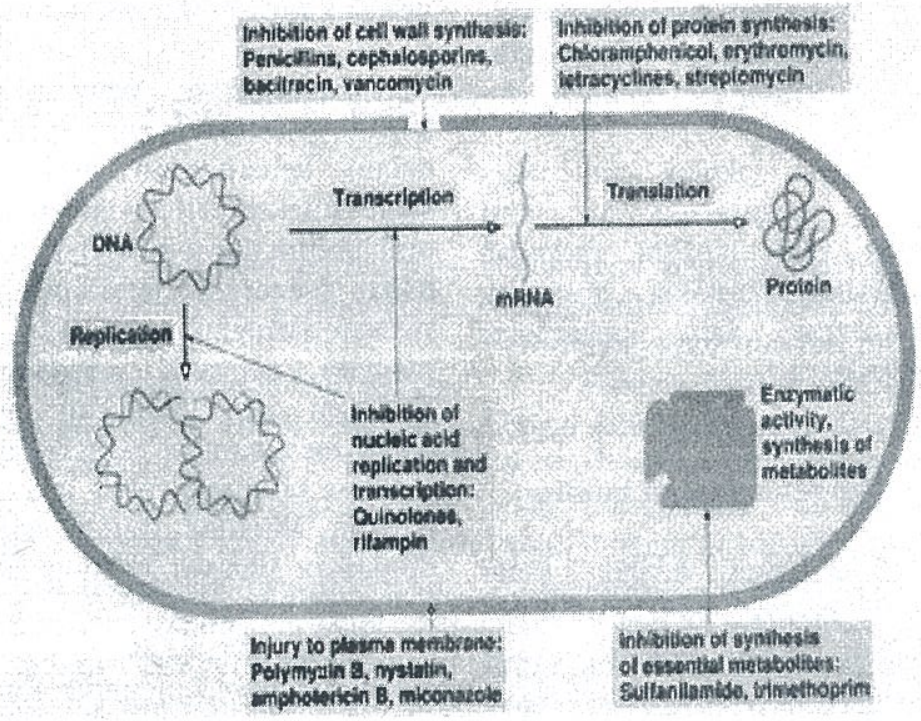

Gambar 2. Berbagai cara antibiotik dalam menghambat aktivitas sel bakteri 


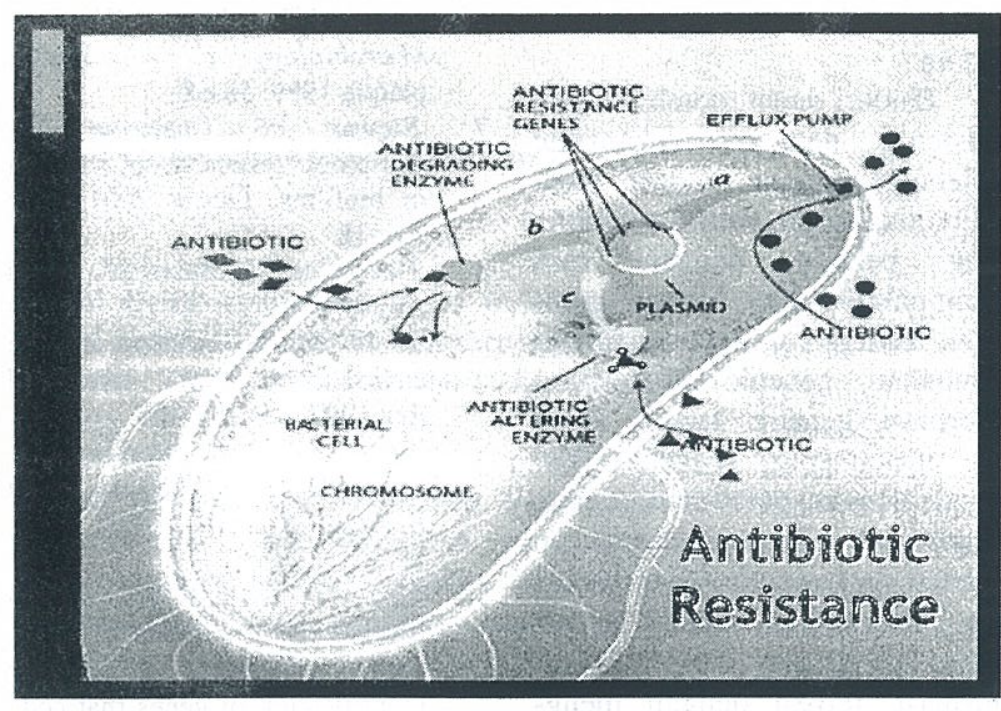

Sambar 3. Cara bakteri mendapat gen resisten

(Sumber: htho:/images medscape.com/pi/editorial/cmecircle/2002/

1692/kollef/slide03.)

bakteri, atau melakukan pemompaan untuk mengeluarkan antibiotika sesegera mungkin saat masuk ke sel, sehingga mencegah kontak dengan targetnya. ${ }^{14}$

Bakteri memperoleh gen resisten dengan beberapa cara, antara lain lewat mutasi DNA bakteri. Mutasi ini diwariskan ke seluruh keturunan yang dihasilkan dari sel inti yang dikenal sebagai proses evolusi vertikal. Bakteri juga dapat melakukan evolusi horisontal, yaitu dengan pertukaran gen antara gel-gel bakteri yang berdekatan. Sebuah mutasi DNA spontan dapat terjadi pada sebuah plasmid dalam suatu sel bakteri. Mutasi ini dapat terjadi dari gen resisten antibiotika. Plasmid bereplikasi dalam sel host dan. ditransfer ke bakteri lain. Jenis transfer genetik ini disebut konjugasi. Plasmid dapat memindahkan informasi genetik antara bakteri yang berbeda. Metode lain dari transfer genetika adalah transduksi, yaitu perpindahan informasi genetik oleh bakteri virus yang disebut bakteriofag.

Fag berikatan pada membran sel bakteri dan menginjeksikan dapat melakukan 2 hal: DNA dapat menjadi non infektif dan rnenggabungkan gen yang membawanya ke dalam DNA bakteri itu sendiri, atau virus dapat berbiak dan rnerusak sel host. ${ }^{15}$

Transfer informasi juga dapat terjadi melalui transposon antara DNA virus dan DNA bakteri. Transposisi berarti transfer genetik menggunakan transposon, bahan yang lebih kecil dari DNA untuk membawa gen resisten antibiotika. Transposon dapat keluar dari plasmid dan bergabung dengan DNA host baru atau kedalam plasmid setelah konjugasi. Informasi genetik yang dibawa transposon masih dapat hidup meskipun plasmid yang mentransfer informasi mati.

\section{Resistensi antibiotik pada bakteri oral biofilm}

Resistensi antibiotik dapat terjadi antara lain karena penggunaan antibiotika yang tidak rasional. Pada kasus penyalahgunaan antibiotika dapat memperburuk keadaan. Penggunaan bahan anti- mikroba untuk pencegahan dan perawatan plak gigi telah banyak dipelajari, namun sebagian besar ditujukan pada organisme dalam suspensi cair (planktonic phase), sedangkan dalam karies dan penyakit inflamasi periodontal, organime target berada dalam bentuk biofilm yang lebih tahan terhadap bahan antimikroba. ${ }^{14,15}$

Tiap bakteri mempunyai suseptibilitas yang berbeda. Spora bakteri dianggap paling resisten, diikuti mikobakteria, kemudian Gram-negatif bentuk. kokus. Resistensi ini dihubungkan dengan adanya enzim degradatif dan impermeabilitas selular. Lapisan dan korteks pada spora bakteri, arabinogalaktan dan komponen dinding sel lain serta membran luar bakteri Gram negatif membatasi konsentrasi biosida aktif yang mencapai daerah target sel-sel bakteri tersebut. Kondisi khas ini ditemukan pada bakteri biofilm, sebagai hasil mekanisme resistensi intrinsik dari adaptasi fisiologi sel. Kolonisasi biofilm ditemukan dalam matriks glycocalyx. Bakteri akan terlindungi dari pengaruh surfaktan, antibodi dan antibiotik, dengan membangun "guard celf' pada bagian atas biofilm yang dapat menetralkan antibiotik secara enzimatik atau mengeluarkan antibiotik berdasarkan perubahan permukaannya. Polianionik dari matriks glycocalyx diduga berperan pada resistensi dalam biofilm. $^{17.18}$.

Terjadinya resistensi antibiotika dalam bakteri biofilm dapat dijelaskan dalam bentuk. hipotesa dibawah ini ${ }^{?}$ :

1. Lambat atau tidak sempurnanya penetrasi antibiotika ke biofilm.

2. Resistensi tergantung pada perubahan lingkungan kimiawi mikro pada biofilm. Produk asam dapat meningkatkan $\mathrm{pH}$ yang dapat secara langsung melawan aksi antibiotika. Perubahan osmo- 
tika biofilm melalui perubahan proporsi relatif dari porin akan mengurangi permeabilitas cell envelope terhadap antibiotika.

3. Adanya mekanisme spekulatif resistensi antibiotika, bahwa subpopulasi milcroorganisme dalam biofilm membentuk bentukan khas dan sangat terlindungi, keadaan fenotip dan diferensiasi sel yang mirip dengan pembentukan spora.

Terapi potensial terhadap bakteri biofilm

Karena resistensi bakteri biofilm bergantung pada agregasi bakteri dalam komunitas multiseluler, dapat dikembangkan strategi terapi dengan merusak struktur multiselular biofilm, dan diharapkan pertahanan tubuh dapat mengatasi infeksi, dan daya guna antibiotik dapat diperbaiki. Terapi potensial dapat meliputi enzim-enzim yang memecah matriks polimer biofilm dan reaksi kimia yang memblok sintesis matriks biofilm.?

\section{Kesimpulan}

Pencegahan pembentukan biofilm merupakan suatu tahap penting guna keberhasilan profilaksis suatu infeksi, mencegah terjadinya kerusakan jaringan gigi yaitu karies maupun penyakit periodontal. Berbagai cara dilakukan untuk dapat menghambat atau merusak struktur biofilm, yaitu dengan bahan antimikroba, antibiotika, enzim penghancur atau pencegah pembentukan plak. Namun tingkat keberhasilannya sangat rendah karena terjadinya resistensi bakteri. Adanya enzim ekstraseluler seperti $\beta$--lactamase dapat mendegradasi atau menginaktivasi beberapa antibiotikuler terutama dari golongan betalaktam.

Bakteri dapat membawa gen resistensi dengan mekanisme molekuler seperti mutasi pada antibiotika target, yaitu antibiotika yang bekerja dengan cara menginaktivasikan protein esensial bakteri sehingga terjadi perubahan genetik. Pertukaran informasi genetik terjadi lewat tiga mekanisme; I) transduksi: terjadi dengan peran virus, yang secara acak mengangkut gen-gen resisted dari genom suatu bakteri dan mentransfer materi genetiknya ke bakteri lain, 2) transformasi: terjadi dengan menggabungkan DNA dari bakteri lain, dan 3) konjugasi: merupakan pertukaran materi genetik dengan kontak cell to cell. Terjadinya mutasi menyebabkan peningkatan produksi enzim target antibiotika, sehingga menghambat antibiotika untuk menginaktitkannya. Mutasi juga menyebabkan perubahan permeabilitas dinding sel terhadap antibiotika.

\section{Daftar Pustaka}

1. Sunarso Brotosoetamo. Peran serta mikroorganisme dalam proses terjadinya karies gigi. KPPIKGXI Jakarta, 1997.

2. Caldwell DE \& Costerton JW. Are bacterial biofllms constrained to Darwin's consept of evolution through natural selection? Microbiologia 1996; 12: $347-58$.

3. Gilbert P, Das 1. Foley I. Biofilm susceptibility to antimicrobials. Adv Dent Res 1997; 11: 160-7.

4. Anderl IN, Franklin MJ. Stewart PS. Role of antibiotic penetration limitation in klebsiella pneumonia biofilm resistance to ampicillin and ciprofloxacin. Anti-microb Agents Chemother 2000; 44: 1818-24.

5. Marsh PD, Bradshaw DJ. Dental plaque as a biofilm. $J$ Ind Microbiol 1995; 15: 169-75.
6. Marsh PD, Martin MY. Oral Microbiology $4^{\text {th }}$ ed. Dental plaque 1999: 58-68.

7. Stewart PS, Costerton JW. Antibiotic resistance of bacteria in biofilms. Lancet 2001; 358: 135-38.

8. Beveridge TJ, Makin SA, Kadu rugamuwa $J \mathrm{~L}, \mathrm{Li} Z$. Interaction between biofilms and the environment FEMS Microbiol Rev 1997; 20: 291-303.

9. Bowden $\mathrm{GH}$ \& Hamilton $\mathrm{IR}$. Survival of oral bacteria. Crit Rev Oral Bioi Med 1998; 9: 5485.

10. Loo CY, Corliss DA, Ganeshkumar N. Streptococcus gordonii biofilm formation: identification of genes that code for biofilm phenotypes. $J$ Bacteriol2000; 182: 1374-82.

11. Mayer C, Moritz R, Kirschner C, Borchard W, Maibaum R, Wingender $J$, et al. The role of intermoleculer interaction: studies on model systems for bacterial biofilm. Int J Bioi Macromol 1999; 26: 3-16.

12. Johansen C, Falholt P, Gram, L. Enzymatic removal and disinfectan of bacterial biofilm. Appl Environ Microbioll997; 63: 3724-8.

13. Lechevallier $M W$, Cawthon $C D$, Lee RG. Inactivation of biofilm bacteria. Appl Environ Microbiol 1988; 54: 2492-9.

14. Badan paM. Informasi penggunaan antibiotik. Majalah Farmacia. Desember2001; 16-17.

15. Kenneth Todar. CALS Pathogen! Pest Resistance Discussion. Bacterial resistance to antibiotic. Oct 25, 1995. Available in http:// IIIw bact.w1se edu/Bact 330n ecture bactres.

16. Wilson M. Susceptibility of oral bacterial biofilms to antimicrobial agents. $J$ Med Microbiol 1996; 44: 79-87.

17. Russell $\mathrm{AD}$. Bacterial resistance to disinfectants: presents knowledge and future problems. $J$ Hosp Infect 1999; 43: 57-68.

18. Hoyle BD, Jass J, Costerton JW. The biofilm glycocalyx as a resistance factor. $J$ Antimicrob Chemother 1990; 26: 1-5. 